\title{
Durable islet effects on insulin secretion and protein kinase A expression following exendin-4 treatment of high-fat diet-fed mice
}

\author{
Maria Sörhede Winzell and Bo Ahrén \\ Division of Medicine, Department of Clinical Sciences, Lund University, BMC, B11, SE-221 84 Lund, Sweden \\ (Correspondence should be addressed to M S Winzell; Email: maria.sorhede_winzell@med.lu.se)
}

\begin{abstract}
Glucagon-like peptide 1 (GLP-1) augments glucose-stimulated insulin secretion (GSIS) through cAMP-induced activation of protein kinase $A(P K A)$, and stimulates $\beta$-cell proliferation and reduces $\beta$-cell apoptosis in rodent islets. This study explored islet GSIS, PKA expression, and markers of apoptosis (caspase 3/7 activity) and proliferation (PKB $\alpha$ and pancreatic and duodenal homeobox gene 1, Pdx-1) after 2 weeks of treatment with the GLP-1 receptor agonist exendin-4 ( $2 \mathrm{nmol} / \mathrm{kg}$ once daily) in female mice with high-fat diet-induced insulin resistance (HFD; $58 \%$ fat by energy). Islets were isolated $20 \mathrm{~h}$ after the last exendin-4 injection, when effects of circulating exendin-4 had vanished. The glucose responsiveness in islets from HFD-fed mice at $8.3 \mathrm{mM}$ glucose was reduced compared with islets from control mice fed a normal diet due to increased basal insulin secretion. However, GSIS increased in islets from HFD-fed exendin-4-treated animals $(0.124 \pm 0.012 \mathrm{ng} / \mathrm{h}$ per islet in HFD-Ex-4 versus $0.062 \pm 0.010$ in HFD, $P=0.006)$. Furthermore, the insulin response to forskolin was increased (2.7 \pm 0.3 in HFD-Ex-4 versus $2.0 \pm 0.2 \mathrm{ng} / \mathrm{h}$ per islet in HFD, $P=0.011)$ and PKAcat expression was increased, while PKAreg was reduced in islets from exendin-4-treated mice. In contrast, protein expression of $\mathrm{PKB} \alpha, \mathrm{Pdx}-1$, and caspase $3 / 7$ activity was not affected by exendin- 4 treatment. We conclude that GLP-1 receptor activation in HFD-fed mice has durable effects on GSIS, in association with augmented signaling through the PKA pathway. These effects are seen beyond those induced by circulating exendin- 4 already after 2 weeks of once-daily treatment in mice, whereas markers for islet proliferation and apoptosis were unaffected by this treatment.
\end{abstract}

Journal of Molecular Endocrinology (2008) 40, 93-100

\section{Introduction}

Glucagon-like peptide (GLP-1) receptor activation, which is a novel treatment for type 2 diabetes (Deacon \& Holst 2006, Drucker \& Nauck 2006, Ahrén 2007), has as a major effect to stimulate insulin secretion (Ahrén 1998). Rodent studies have suggested that GLP-1 receptor activation inhibits islet apoptosis and stimulates $\beta$-cell proliferation (Xu et al. 1999, Perfetti et al. 2000, Stoffers et al. 2000, Wang \& Brubaker 2002, Egan et al. 2003, Li et al. 2003). GLP-1 receptor activation in islets involves stimulation of adenylate cyclase activity leading to increased formation of cAMP and activation of protein kinase A (PKA; Gromada et al. 1998). This in turn results in altered ion channel activity and intracellular $\mathrm{Ca}^{2+}$ handling, eliciting exocytosis of insulin granules, resulting in insulin secretion (Gromada et al. 1998, Holz 2004b). The longterm effect of GLP-1 receptor activation in inhibition of apoptosis also seems to be connected to the cAMP/PKA signaling pathway, through its involvement in activation of pancreatic and duodenal homeobox gene $1(\operatorname{Pdx}-1)$, which stimulates insulin gene transcription and activates proliferative pathways in the $\beta$-cell (Perfetti et al. 2000, Stoffers et al. 2000, Wang et al. 2001, Drucker 2003, Hui et al. 2003, Li et al. 2005b). Protein kinase $\mathrm{B} \alpha(\mathrm{PKB} \alpha)$ regulates proliferative pathways in $\beta$-cells (Wrede $e t$ al. 2002, Dickson \& Rhodes 2004, Li et al. 2005a) after activation of the PKA pathway and phosphorylation of the cAMP response element-binding protein (CREB), resulting in activation of insulin receptor substrate 2 (IRS-2) and phosphatidylinositol 3-kinase (PI-3K; Jhala et al. 2003, Park et al. 2006). GLP-1 receptor activation has been shown to reduce cytokine-induced apoptosis through inhibition of caspase 3 activity (Li et al. $2005 a$ ), and this effect of GLP-1, which is mediated through $\mathrm{PKB} \alpha$, contributes to maintain $\beta$-cell mass. PKA is thus a key enzyme in islet GLP-1 signaling.

The islet effects and mechanisms of GLP-1 receptor activation have mainly been established in clonal cells and isolated islets or in vivo in animal experiments (Greig et al. 1999, Perfetti et al. 2000, Stoffers et al. 2000, Wang \& Brubaker 2002, Wrede et al. 2002, Egan et al. 2003). These studies have been designed to examine the effects of GLP-1 receptor activation when the ligand is present, either acutely or during a long-term treatment period. However, whether the islet effects are also evident after long-term treatment when the GLP-1 receptor ligand is no longer present is not known, that is, it is not known 
whether durable and persistent islet effects are induced by GLP-1 receptor activation. In this study, we therefore examined the long-term effects of GLP-1 receptor activation in mice, when the ligand had been cleared from the circulation. We studied islets from insulinresistant mice following a 2-week treatment period with exendin-4, which is a selective GLP-1 receptor agonist (Montrose-Rafizadeh et al. 1997). Insulin resistance was induced by feeding female mice with a high-fat diet (HFD), which is a model that has been extensively examined as a tool for studying islet function (Winzell \& Ahrén 2004). High-fat feeding in female mice results in insulin resistance, as demonstrated by euglycemic hyperinsulinemic clamp techniques (Pacini et al. 2001). High-fat feeding also compromises islet function, leading to reduced glucose-stimulated insulin secretion (GSIS), resulting in glucose intolerance (Pacini et al. 2001, Ahrén \& Pacini 2002, Winzell \& Ahrén 2004). Recently, we demonstrated that activation of GLP-1 receptors through exendin-4 administration to insulin-resistant HFD-fed female mice increased GSIS and elevated the islet sensitivity to cAMP, observed after addition of forskolin to isolated islets (Sörhede Winzell \& Ahrén 2004). In this study, we explored the durable islet effects after long-term exendin- 4 administration to female mice fed a HFD beyond the acute effect of the peptide. To ensure, no remaining circulating biologically active exendin-4, islets were isolated $20 \mathrm{~h}$ after the last injection. This time point is beyond the rapid half-life of exendin- 4 in rodents, which is $2 \mathrm{~h}$ in rats (Parkes et al. 2001), and also at a time point beyond the glucose-lowering effect of acute exendin-4 treatment (Sörhede Winzell \& Ahrén 2004, Gedulin et al. 2005).

\section{Materials and Methods}

\section{Animals and study design}

Five-week old female C57BL/6J mice weighing $\sim 20 \mathrm{~g}$ were purchased from Taconic (Skensved, Denmark). The animals were maintained in a temperature-controlled room $\left(22^{\circ} \mathrm{C}\right)$ on a $12 \mathrm{~h}$ light: $12 \mathrm{~h}$ darkness cycle (lights on at $0600 \mathrm{~h}$ ). One week after arrival, the mice were divided into two groups and fed either a normal diet (ND, $11 \%$ fat by energy) or a HFD ( $58 \%$ fat by energy; Research Diets Inc., New Brunswick, NJ, USA) and kept on the different diets for 8 weeks prior to the exendin-4 treatment. The mice given the HFD were then divided into two groups; one group was injected intraperitoneally once daily (at $1500 \mathrm{~h}$ ) with exendin-4 (Sigma) in $250 \mu \mathrm{l}$ saline supplemented with $0 \cdot 1 \%$ BSA (MP, Biomedicals Inc., Illkirch, France), while the control group received vehicle only. The mice continued on the HFD during the exendin- 4 treatment. The dose of exendin- 4 was $2 \mathrm{nmol} / \mathrm{kg}$ daily, a dose that has previously been shown to effectively reduce plasma glucose levels in mice (Wang \& Brubaker 2002, Sörhede Winzell \& Ahrén 2004). The glucose-lowering effect is short-lived, due to a relatively short half-life of exendin- 4 in rodents, being $\sim 120 \mathrm{~min}$ in rats after i.p. injection (Parkes et al. 2001). Thus, i.p. administration of exendin-4 in HFD-fed mice reduced plasma glucose, through an effect that lasted for $<2 \mathrm{~h}$ (Sörhede Winzell \& Ahrén 2004). Islets were therefore isolated $20 \mathrm{~h}$ after the last dose of exendin-4, to make sure that the acute effects of the peptide had vanished. Body weight was recorded and basal blood samples were taken before the start of the exendin- 4 administration and just before islet isolation from the intraorbital, retrobulbar plexus in non-fasted, anesthetized $(20 \mathrm{mg} / \mathrm{kg}$ fluanisone $/ 0 \cdot 8 \mathrm{mg}$ per $\mathrm{kg}$ fentanyl; Hypnorm, Janssen, Beerse, Belgium and $10 \mathrm{mg} / \mathrm{kg}$ midazolam; Dormicum, Hoffman-LaRoche, Basel, Switzerland) mice. In one series of experiments, the acute effects of i.p. injection with exendin-4 on insulin and glucose levels were examined. Mice, fed the HFD for 8 weeks, were injected intraperitoneally with $2 \mathrm{nmol} / \mathrm{kg}$ exendin- 4 or with saline (at $1500 \mathrm{~h}$ ) and returned to their cages. Blood samples were taken just before and 1,2 , and $4 \mathrm{~h}$ after the injections with exendin- 4 or saline. The mice were anesthetized just prior to the blood sampling and different mice were used at the different time points. All samples were collected in heparinized tubes and plasma was immediately separated and stored at $-20^{\circ} \mathrm{C}$ until analyzed for glucose and insulin. The study was approved by the local Animal Ethics Committee in Lund/Malmö, Sweden.

\section{Islet isolation and insulin secretion}

Islets were isolated after collagenase digestion of pancreata. For insulin secretion studies, batches of islets were pre-incubated in HEPES balanced salt solution (HBSS) containing $125 \mathrm{mM} \mathrm{NaCl}, 5.9 \mathrm{mM} \mathrm{KCl}, 1.28 \mathrm{mM}$ $\mathrm{CaCl}_{2}, 1 \cdot 2 \mathrm{mM} \mathrm{MgCl}$, and $25 \mathrm{mM}$ HEPES (pH 7.4) with $5 \cdot 6 \mathrm{mM}$ glucose for $60 \mathrm{~min}$. Thereafter, islets in groups of three were incubated in $200 \mu \mathrm{l} \mathrm{HBSS}$ with glucose concentrations of 2.8 and $16.7 \mathrm{mM}$, with or without $2.5 \mu \mathrm{M}$ forskolin (Sigma) and incubated for $60 \mathrm{~min}$ at $37^{\circ} \mathrm{C}$. After incubation, aliquots of $25 \mu \mathrm{l}$ in duplicates were collected and stored at $-20^{\circ} \mathrm{C}$ until insulin analysis.

\section{Perifusion of isolated islets}

Perifusion of islets was performed as previously described in detail (Skoglund et al. 1988). In brief, freshly isolated islets were pre-incubated in HBSS at $2 \cdot 8 \mathrm{mM}$ glucose for $60 \mathrm{~min}$. Then, batches of 20 islets were sandwiched between two layers of gel (Bio-Gel P4, Bio-Rad). The HBSS was kept at $37^{\circ} \mathrm{C}$. Islets were perifused at a flow rate of $1 \mathrm{ml} / \mathrm{min}$ with $16.7 \mathrm{mM}$ glucose for $30 \mathrm{~min}$. Fractions were collected at 1-min interval and analyzed for insulin. 


\section{Western blotting}

The protein expression levels of PKA, Pdx-1, and PKB $\alpha$ in islets were analyzed using western blot. For these studies, islets were kept on ice and washed thrice in Hank's buffer (Sigma). The samples were homogenized in lysis buffer containing $150 \mathrm{mM} \mathrm{NaCl}, 2 \mathrm{mM}$ EDTA, $20 \mathrm{mM}$ Tris- $\mathrm{HCl}(\mathrm{pH} 7 \cdot 5), 1 \%$ Triton X-100 and $0.2 \%$ protease inhibitor cocktail (Sigma), and $1 \mu \mathrm{M}$ ocadeic acid (Alexis Co., Lausen, Switzerland). The total amount of proteins in each sample was measured using BCA protein assay reagent kit (Pierce, Rockford, IL, USA). Aliquots of islet homogenates corresponding to equal amount of total protein $(80 \mu \mathrm{g})$ were separated by SDS-PAGE, and then electroblotted onto nitrocellulose membranes (Hybond-c extra, Amersham Pharmacia Biotech). The membranes were probed with primary antibodies against the regulatory as well as the catalytic subunits of PKA (PKA1ßreg and PKA1 acat, Santa Cruz Biotechnology, Santa Cruz, CA, USA), rabbit anti-Pdx-1 (a kind gift from Prof. P Serup, Hagedorn Inst., Copenhagen, Denmark), sheep anti-PKB $\alpha$ (Upstate, Charlottsville, VA, USA), or rabbit anti-phospho-PKB $\alpha$ (Biosource, Nivelles, Belgium). The secondary antibody was either horseradish peroxidase-conjugated goat anti-rabbit immunoglobulin G (IgG) (Amersham Pharmacia Biotech) or rabbit antisheep IgG (Upstate). The blots were developed by enhanced chemiluminescense (SuperSignal, Pierce), and the proteins were detected and quantified using a CCD camera (LAS 1000, Fuji, Tokyo, Japan).

\section{Insulin and glucose measurements}

Insulin was determined radioimmunochemically using a guinea pig anti-rat insulin antibody, ${ }^{125}$ I-labeled human insulin as tracer and rat insulin as standard (Linco Res., St Charles, MO, USA). Free and bound radioactivity was separated using an anti-IgG (goat antiguinea pig) antibody. Glucose was measured with the glucose oxidase method using $2 \cdot 2^{\prime}$-azino-bis (3-ethylbenzothialozine-6-sulfonate) (ABTS) as substrate and the absorbance was measured at $420 \mathrm{~nm}$ on a microtiter plate reader (Fluostar/Polarstar Galaxy, BMG Labtechnologies, Offenburg, Germany).

\section{Caspase $3 / 7$ activity}

Caspase 3/7 activity was measured using a commercial Caspase 3/7 Glo Assay kit (Promega Corp.). Briefly, islets were lysed in lysis buffer (as described above) and centrifuged at $10000 \mathrm{~g}$ for $1 \mathrm{~min}$. The supernatant was collected and analyzed for protein content and for caspase 3/7 activity. Substrate (Z-DEVD-R110) for caspase $3 / 7$ was added and luminescence was measured using a microtiter plate reader (Victor 2, Wallac, PerkinElmer, Turku, Finland).

\section{Statistical analysis}

All data are presented as mean \pm s.E.M. The area under the curve (AUC) was determined by the trapezoid rule for the insulin curves in the perifusion experiments. Statistical differences were calculated either using Student's $t$-test or for multiple comparisons one-way ANOVA followed by Tukey's post hoc test. Differences were considered statistically different at $P<0 \cdot 05$.

\section{Results}

\section{Body weight and basal glucose and insulin levels}

After 8 weeks of HFD, mice had gained significantly in body weight compared with ND-fed mice $(27 \cdot 2 \pm 0 \cdot 7 \mathrm{vs}$ $22 \cdot 7 \pm 0 \cdot 3 \mathrm{~g}$ in ND, $P<0 \cdot 001)$. During the subsequent 2 weeks, high-fat feeding continued and the mice were treated with either saline or exendin- 4 . Following this 2-week treatment period, body weight was $27 \cdot 0 \pm 0 \cdot 6 \mathrm{~g}$ in saline-treated mice versus $25.9 \pm 0.8 \mathrm{~g}$ in exendin4-treated mice $(P=0.051$ over the 2-week treatment period). Basal glucose was increased in mice fed the HFD for 8 weeks $(7 \cdot 6 \pm 0 \cdot 3$ in ND-fed mice versus $8.7 \pm 0.3 \mathrm{mM}$ in HFD-fed mice, $P=0.007, n=36$ in each group), while basal insulin levels were similar in the two dietary groups (ND: $223 \pm 43$ versus HFD: $310 \pm 68 \mathrm{pM}, n=16$ and 17 respectively). After the 2-week treatment period with exendin-4 or saline, basal glucose and insulin levels were not altered in the ND and HFD control groups (injected with saline). However, in the HFD-fed mice, 2 weeks of exendin- 4 treatment and $20 \mathrm{~h}$ after the last exendin- 4 administration, reduced basal insulin levels were evident, while plasma glucose was not different from HFD-fed control mice (Table 1).

Table 1 Plasma glucose and insulin, islet insulin content, and caspase $3 / 7$ activity after 2 weeks of exendin- 4 administration to high-fat diet (HFD)-fed female C57BL/6J mice. Blood samples were taken and islets were isolated $20 \mathrm{~h}$ after the last exendin- 4 injection

\begin{tabular}{|c|c|c|}
\hline $\begin{array}{c}\text { ND } \\
(n=16)\end{array}$ & $\begin{array}{c}\text { HFD } \\
(n=17)\end{array}$ & $\begin{array}{c}\text { HFD-Ex-4 } \\
\quad(n=19)\end{array}$ \\
\hline $7 \cdot 8 \pm 0 \cdot 3$ & $9 \cdot 1 \pm 0.2^{*}$ & $9 \cdot 2 \pm 0.2^{*}$ \\
\hline $221 \pm 41$ & $294 \pm 42$ & $122 \pm 22^{\dagger}$ \\
\hline $49 \pm 7$ & $85 \pm 14^{*}$ & $90 \pm 8^{*}$ \\
\hline $310 \pm 19$ & $300 \pm 17$ & $314 \pm 7$ \\
\hline
\end{tabular}

Plasma glucose $(\mathrm{mM})$ Plasma insulin (pM) Islet insulin (ng/islet) Islet caspase $3 / 7$ activity (AU/mg protein; $n=6$ )

The results are expressed as mean \pm S.E.M. ${ }^{*} P<0.001$ compared with ND, ${ }^{\dagger} P<0.05$ compared with HFD, AU=arbitrary units. 


\section{Acute effects of exendin-4}

Plasma glucose levels were significantly reduced after $1 \mathrm{~h}$ in mice injected with exendin- 4 compared with HFD-fed control mice $(6 \cdot 6 \pm 0 \cdot 3$ vs $8 \cdot 3 \pm 0 \cdot 2 \mathrm{mM}$ in control mice, $P<0 \cdot 001, n=10$ in each group), while after 2 and $4 \mathrm{~h}$, there were no differences between the treatment groups. Plasma insulin was similar at all time points in exendin-4-treated mice compared with control mice.

\section{In vitro insulin secretion}

Insulin secretion was measured after 1-h static incubation of the islets. Basal insulin secretion at $2 \cdot 8 \mathrm{mM}$ glucose was similar in the different groups, although it was slightly increased in islets isolated from HFD-fed mice compared with $\mathrm{ND}$, which was not apparent in islets from exendin-4-treated mice (Fig. 1). At $8.3 \mathrm{mM}$ glucose, insulin secretion was increased in islets from exendin-4-treated mice compared with islets from both ND- and HFD-fed mice $(0 \cdot 124 \pm 0 \cdot 012 \mathrm{ng} / \mathrm{h}$ per islet in HFD Ex- 4 versus $0 \cdot 062 \pm 0 \cdot 010$ in HFD, $P=0 \cdot 006$ ), while at $16.7 \mathrm{mM}$ glucose, there was no difference in insulin secretion between the different treatment groups (Fig. 1). Thus, when calculating the fold increase in insulin in response to elevation of the glucose concentration from $2 \cdot 8$ to $16 \cdot 7 \mathrm{mM}$, insulin secretion increased $6 \cdot 5 \pm 1 \cdot 2$-fold in ND-fed mice, whereas in HFD-fed mice, GSIS was raised only by $3 \cdot 8 \pm 0 \cdot 5$-fold. Islets from exendin-4-treated mice demonstrated improved GSIS, which was increased by $8 \cdot 5 \pm 1 \cdot 7$-fold at $16.7 \mathrm{mM}$ glucose $(P=0.02$ compared with the HFD control), being similar to what was found in islets from ND-fed mice.

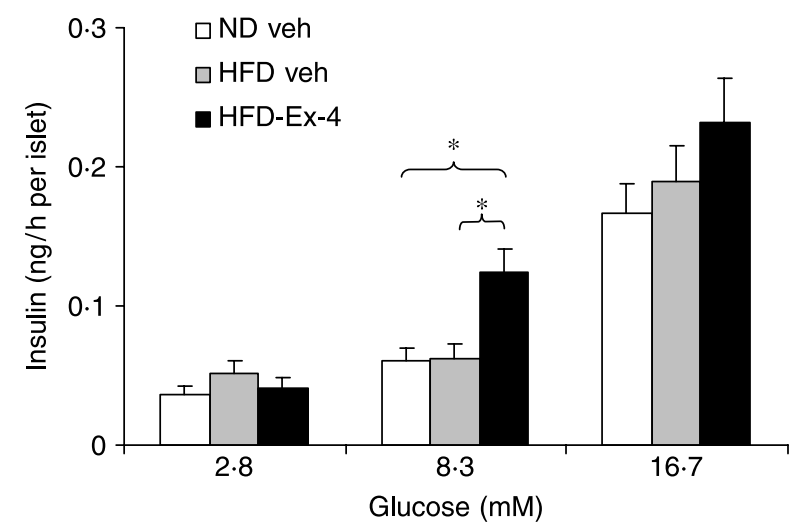

Figure 1 Insulin secretion in freshly isolated islets from normal diet (ND)- or high-fat diet (HFD)-fed mice after 2 weeks of oncedaily injection with vehicle or exendin-4 (HFD-Ex-4). Islets were isolated $20 \mathrm{~h}$ after the last exendin-4 injection. Batches of three islets were incubated at 2.8 or $16.7 \mathrm{mM}$ glucose for $1 \mathrm{~h}$. Values are presented as mean \pm S.E.M. from four different experiments with eight observations in each condition. ${ }^{\star} P<0.01$.
The potentiation of GSIS by forskolin was augmented in the HFD-fed group compared with the ND group $(1 \cdot 3 \pm 0 \cdot 1$ in $\mathrm{ND}$ and $2 \cdot 0 \pm 0 \cdot 2 \mathrm{ng} /$ islet per hour in HFD, $P=0 \cdot 005)$, and islets from exendin- 4 -treated mice demonstrated further augmentation of forskolininduced potentiation of GSIS $(2 \cdot 7 \pm 0 \cdot 3 \mathrm{ng} /$ islet per hour in HFD Ex-4, $P=0 \cdot 011$ compared with HFD).

Insulin secretion was also studied in islet perifusion experiments. In these experiments, islets from exendin4-treated mice or HFD-fed control mice were initially perifused with $2.8 \mathrm{mM}$ glucose. Raising the concentration from $2 \cdot 8$ to $16 \cdot 7 \mathrm{mM}$ elicited a biphasic insulin response. The response to glucose was significantly increased after exendin- 4 treatment compared with control islets from HFD-fed mice (Fig. 2A). The area under the insulin curve $\left(\mathrm{AUC}_{\text {ins }}\right)$ was calculated for the first (10-13 min) and the second (14-30 min) phases of
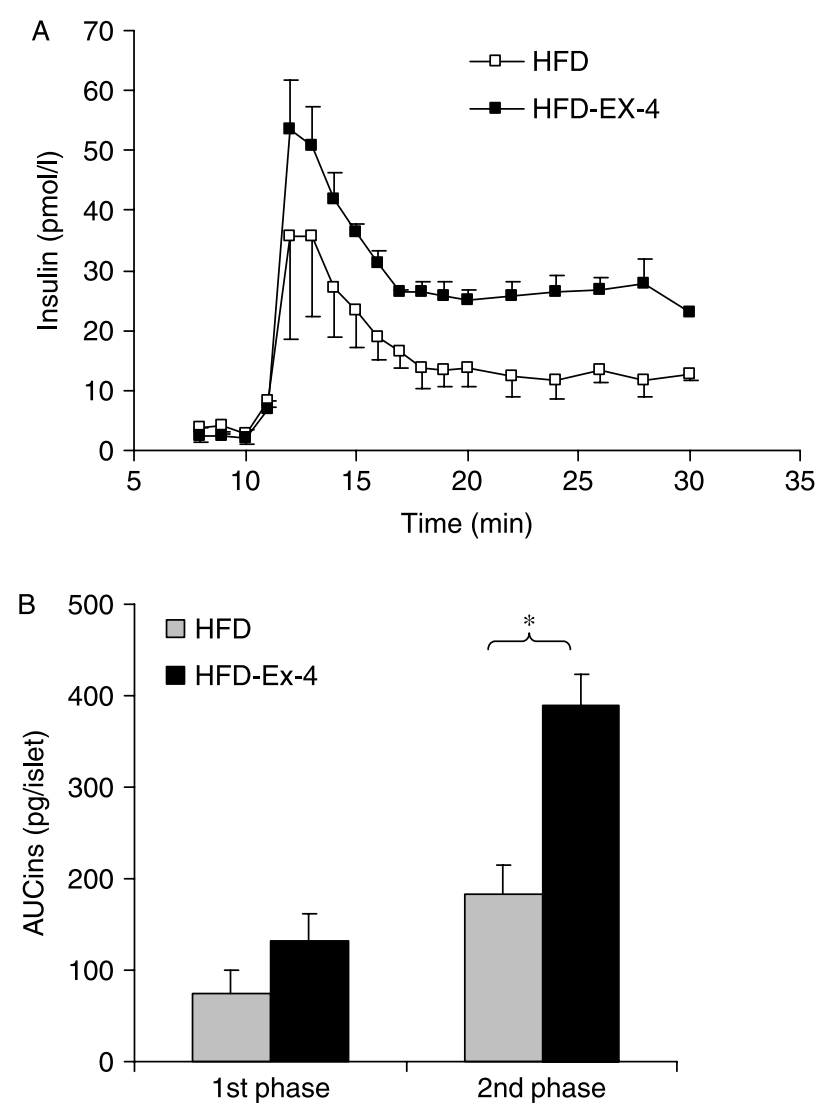

Figure 2 (A) Insulin secretion from perifused freshly isolated islets from high-fat diet (HFD)-fed mice with or without exendin-4 treatment (HFD-Ex-4). Islets were isolated $20 \mathrm{~h}$ after the last exendin-4 injection. Islets were perifused in the presence of $2.8 \mathrm{mM}$ glucose for $10 \mathrm{~min}$ prior to elevation of the glucose concentration to $16.7 \mathrm{mM}$. Fractions were collected at 1-min interval and analyzed for insulin. (B) The area under the insulin curve for the first (10-13 min) and the second (14-30 min) phases of insulin secretion in the different treatment groups. Values are presented as mean \pm S.E.M. from three independent experiments. ${ }^{\star} P<0.05$. 
secretion. There was a tendency to increased first-phase insulin secretion and a significant increase in the second phase of insulin secretion in islets from exendin-4-treated mice compared with islets from HFD-fed control mice $(P=0 \cdot 02$; Fig. 2B). Insulin content was elevated in islets from mice fed the HFD, but with no difference between the control and the exendin-4 group (Table 1). Thus, the increased insulin secretion in exendin-4-treated islets was not due to increased insulin content.

\section{PKAcat and PKAreg expression after exendin-4 administration}

The expression of the catalytic subunit of PKA (PKAcat) was, after correction to the actin expression, increased in the two HFD-fed groups $(P=0 \cdot 020$; Fig. 3A $)$, but without significant difference between islets from control and exendin-4-treated mice. On the contrary, the regulatory subunit of PKA (PKAreg) expression level was reduced in islets from exendin-4-treated mice compared both with HFD control islets $(P=0 \cdot 05)$ and with ND control islets $(P=0 \cdot 001)$. The expression of PKAreg was also significantly reduced in islets from HFD-fed mice compared with ND $(P=0 \cdot 016)$. Therefore, a significantly elevated PKAcat/PKAreg ratio was evident in islets from exendin4-treated mice $(P=0 \cdot 049$; Fig. 3A).

\section{Markers for islet apoptosis and proliferation}

Caspase 3/7 activity was used as a measure of islet apoptosis. Following 10 weeks of high-fat feeding, no
A

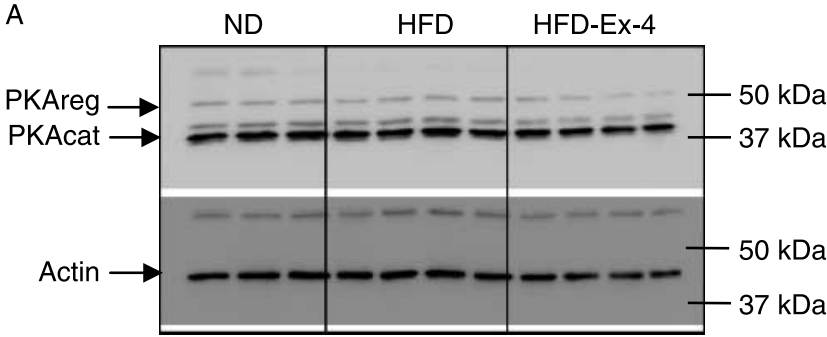

B

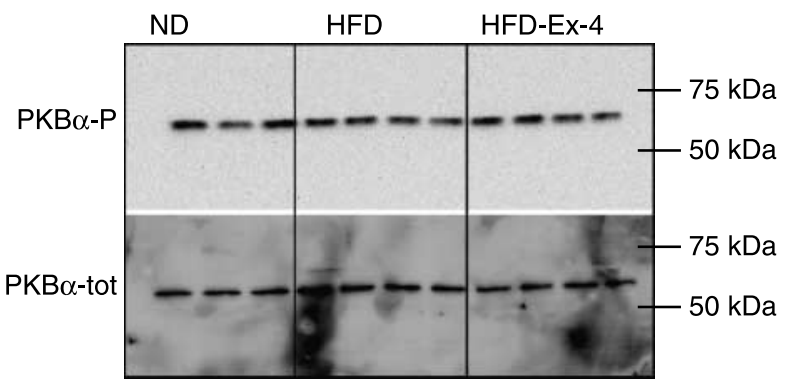

C

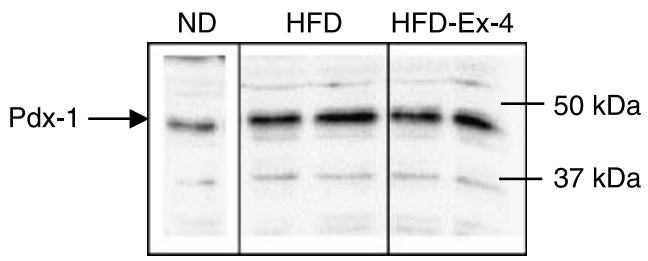

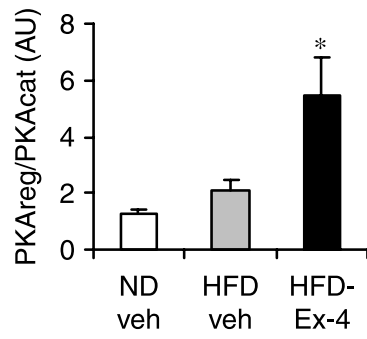
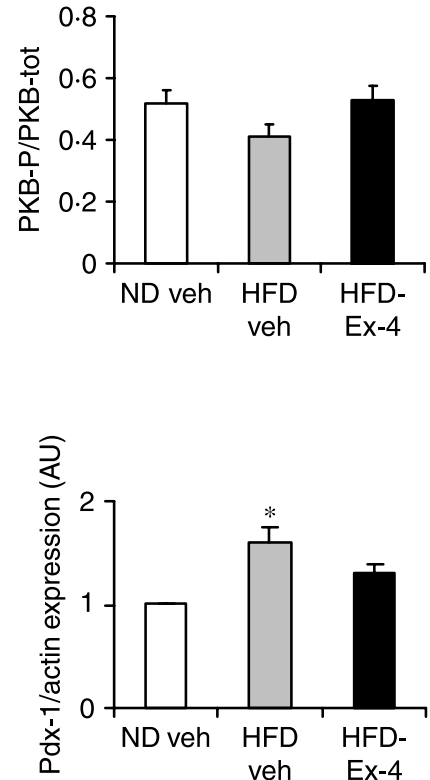

Figure $3(A)$ Islet expression of the regulatory (PKAreg) and catalytic (PKAcat) subunits of PKA assessed by western blot after 2 weeks of once-daily injection of exendin-4 to HFD-fed mice and in control mice fed the HFD or ND. The ratio of PKAcat and PKAreg is presented. (B) Islet protein expression of total and phosphorylated $\mathrm{PKB} \alpha$ and $(\mathrm{C}) \mathrm{Pdx}-1$ expression in controls and exendin-4-treated islets isolated $20 \mathrm{~h}$ after the last exendin-4 injection. Representative immunoblots are shown and the results are presented as mean \pm S.E.M. from three independent experiments. The expression levels of the different proteins are correlated to the $\beta$-actin expression in each lane. ${ }^{*} P<0.05$. 
change in caspase $3 / 7$ activity was observed compared with islets from ND-fed mice (Table 1). Treatment with exendin- 4 for 2 weeks did not affect the islet caspase $3 / 7$ activity (Table 1), which was similar to islets from both ND- and HFD-fed mice.

As a marker of islet proliferation, we measured the expression levels of $\mathrm{Pdx}-1$ and $\mathrm{PKB} \alpha$ expression and phosphorylation in islets from the different treatment groups. Islets were incubated with insulin to induce $\operatorname{PKB} \alpha$ phosphorylation, and by the use of $\operatorname{PKB} \alpha$ phospho-specific antibodies, we demonstrated that the $\mathrm{PKB} \alpha-\mathrm{P} / \mathrm{PKB} \alpha_{\text {tot }}$ ratio was similar in all the three treatment groups (Fig. 3B). HFD increased the expression of Pdx-1 in islets compared with ND suggesting increased proliferation in these islets (Fig. 3C). There was no difference in the expression levels of the proliferative markers $\mathrm{Pdx}-1$ or $\mathrm{PKB} \alpha$ in islets from exendin-4-treated HFD-fed mice.

\section{Discussion}

GLP-1 receptor activation potentiates GSIS through cAMP formation with subsequent activation of PKA, resulting in multiple effects within the pancreatic islets including exocytosis, ion-transport, metabolism, and proliferation (Gromada et al. 1998, Holz 2004a, Drucker 2006, Doyle \& Egan 2007). Long-term activation of GLP-1 receptors has been extensively examined in cultured cells and islets and also in in vivo studies in rodents where GLP-1 receptors were activated with daily injections or through continuous administration of exendin-4 or GLP-1 (Greig et al. 1999, Perfetti et al. 2000, Stoffers et al. 2000, Wang \& Brubaker 2002, Egan et al. 2003, Park et al. 2006). However, whether the GLP-1induced in vivo effects remain after the GLP-1 receptor agonist is cleared from the circulation is not established. Therefore, the present study explored whether islet effects (insulin secretion and proliferation/apoptosis) are sustained after long-term in vivo GLP-1 receptor activation in HFD-fed mice when exendin- 4 had been cleared from the circulation. The experiments were performed in islets isolated $20 \mathrm{~h}$ after the last exendin-4 injection. The effect of exendin- 4 is short-lived in rodents, due to a relatively short half-life of the peptide, being $\sim 120$ min in rats after i.p. administration (Parkes et al. 2001). We have also recently demonstrated that the glucose-lowering effect of exendin-4 in mice was significant only during the first hour after injection (Sörhede Winzell \& Ahrén 2004), which was confirmed in this study. The increased insulin secretion was evident by the sustained insulin levels in the presence of reduced glycemia. Therefore, $20 \mathrm{~h}$ after the last exendin- 4 administration, that is, the time when islets were isolated in this study, blood glucose was similar to HFD control mice, while, however, insulin levels were reduced compared with HFD-fed control mice. This indicates that insulin sensitivity was improved after exendin- 4 treatment. Increased insulin sensitivity may be due to improved insulin action, caused either by an indirect or direct effect, or alternatively through reduced glucagon levels, which has been observed after exendin- 4 treatment in humans (Kolterman et al. 2003). The finding of increased insulin sensitivity is in agreement with a previous study in obese Zucker rats, where exendin-4 had been washed out for $24 \mathrm{~h}$ prior to blood sampling, and where there was no observed effect on plasma glucose but reduced insulin levels (Gedulin et al. 2005). Another study demonstrated that long-term activation of GLP-1 receptors in diabetic rodents resulted in improved insulin sensitivity (Young et al. 1999). Therefore, the effect of exendin- 4 on insulin sensitivity needs to be explored further, but was beyond the scope of the present study.

In this study, we show that islets from HFD-fed mice displayed impaired glucose sensitivity of the islets, which was mainly due to increased basal insulin secretion, while the response to elevated cAMP levels by forskolin stimulation was augmented. This is in agreement with earlier studies demonstrating that the response to non-glucose stimulus, including GLP-1, is augmented in islets from HFD-fed mice (Simonsson \& Ahrén 1998, Sörhede Winzell \& Ahrén 2004). After administration of exendin- 4 , both the response to glucose and elevated cAMP levels were significantly increased, suggesting a persistent effect of GLP-1 receptor activation in the islets. The improved response to cAMP in islets from HFD-fed mice was associated with increased expression of PKAcat and particularly in increased PKAcat/PKAreg ratio. PKA consists of two catalytic subunits bound to a regulatory subunit dimer and upon binding cAMP the complex dissociates into two active catalytic subunits and a regulatory subunit (Skalhegg \& Tasken 2000). Since PKAcat is assembled in a fully phosphorylated and active enzyme, which is regulated by its association with the regulatory subunit making the active enzyme released upon binding to cAMP (Taylor et al. 2005), it is most likely that the elevated PKAcat/PKAreg ratio increased basal PKA activity. The results with elevated expression of PKAcat after HFD and GLP-1-based treatment corroborate with our finding that the insulin response to forskolin was increased in parallel. Thus, in HFD-fed mice, compared with ND-fed mice, the insulin response to forskolin was increased and exendin-4 further augmented this increase. Hence, the elevated expression of PKA is transferred to an increased insulin response to cAMP; therefore, improved sensitivity to cAMP seems to be one mechanism for islet adaptation to insulin resistance and this is further improved by GLP-1 receptor activation. The more exact mechanism behind the improved cAMP sensitivity deserves to be further explored. 
Exendin- 4 treatment also improved the islet sensitivity to glucose as illustrated both in static batch incubations of islets and in perifusion experiments, and that the second phase of insulin secretion was increased after the exendin-4 treatment. Insulin secretion is triggered by glucose metabolism to induce increased influx of $\mathrm{Ca}^{2+}$ to elicit insulin exocytosis (Henquin 2000). The second phase of insulin secretion is dependent on other signals to amplify and maintain insulin secretion during high glucose concentrations and activation of PKA by cAMP is one such important signal (Henquin et al. 2003).

GLP-1 regulates proliferation and apoptosis through several pathways including $\operatorname{PKA}, \operatorname{PKB} \alpha$, and $\mathrm{Pdx}-1$ (Drucker 2003, Egan et al. 2003, Hui et al. 2003, Li et al. 2005a). The HFD in itself induced Pdx-1 expression when compared with ND-fed mice, suggesting that one adaptation process to insulin resistance is increased islet proliferation, which may form the basis of the increased $\beta$-cell mass in insulin resistance demonstrated in animal models (Del Zotto et al. 2004). We found, however, no significant additive effect on Pdx-1 expression $20 \mathrm{~h}$ after the last exendin-4 treatment in the 2-week treatment regimen. This is different from the previously demonstrated increase in Pdx-1 expression by exendin- 4 in normal and diabetic mice (db/db; Stoffers et al. 2000). In this study, once-daily exendin- 4 treatment resulted in significantly increase $\mathrm{Pdx}-1$ expression in association with reduced plasma glucose levels in $\mathrm{db} / \mathrm{db}$ mice, however, there was no effect observed on hemoglobulin A1C $\left(\mathrm{HbA}_{1 \mathrm{C}}\right)$ levels, indicating that the glucose-lowering effect was dependent on circulating exendin-4. It is therefore possible that the increased expression of Pdx-1 is also dependent on circulating exendin- 4 .

$\operatorname{PKB} \alpha$ has also been demonstrated to play a crucial role in $\beta$-cell survival and in clonal $\beta$-cells. For example, overexpression of $\mathrm{PKB} \alpha$ could prevent the $\beta$-cells from fatty acid-induced apoptosis (Wrede $e t$ al. 2002), and in mouse islets overexpression of $\mathrm{PKB} \alpha$ resulted in increased proliferation (Tuttle et al. 2001). In this study, we observe no effect on the expression level or the phosphorylation degree of $\mathrm{PKB} \alpha$ in islets from exendin4-treated HFD-fed mice, $20 \mathrm{~h}$ after the last exendin-4 administration, which shows that effects on GSIS and proliferation/apoptosis after GLP-1 receptor activation are dissociated processes. Earlier studies have demonstrated that in mice with streptozotocin-induced islet apoptosis, exendin- 4 treatment reduced caspase activity (Li et al. 2003). However, since HFD for 10 weeks in itself did not induce caspase $3 / 7$ activity, there was no effect on this apoptosis marker after exendin-4 treatment. The lack of effect on proliferation and apoptosis markers by exendin- 4 in this study may have several explanations. One explanation is that the treatment period was relatively short, that is, only 2 weeks, and a longer period would be required for establishing a robust effect. An alternative explanation would be that a low single daily dose of exendin- 4 would be insufficient to affect proliferation or apoptosis, although effects on insulin secretion are seen. A third possibility would be that exendin-4 lacks effect on proliferation or apoptosis in this model of HFD feeding. Therefore, longer treatment period with a higher dose of exendin- 4 would be required to rule out an effect of exendin- 4 on these parameters also in this model, as been observed in other studies (Greig et al. 1999, Gedulin et al. 2005). It should also be emphasized that mice eat normally during the dark phase of the 24-h period, starting at $1800 \mathrm{~h}$, and exendin- 4 in this study was given to mice in the post-absorptive phase when plasma glucose is at the basal level. A final possibility explaining the lack of effect of exendin- 4 on proliferation and apoptosis in this model would therefore be that exendin- 4 was not given during the absorptive phase.

In summary, we conclude that 2-week GLP-1 receptor activation, beyond any direct effect of the ligand, augments the islet adaptation to HFD-induced insulin resistance in regard to insulin secretion, through a PKAdependent mechanism, and this is seen independently from any effect on proliferation or apoptosis.

\section{Acknowledgements}

The authors like to thank Kristina Andersson, Lena Kvist, Lilian Bengtsson, and Caroline Kiaer for excellent technical assistance. This work was supported by the Swedish Research Council (grant no. 6834), Albert Påhlsson, Crafoord, Novo Nordisk, Swedish Diabetes Foundations, Region Skåne and Faculty of Medicine, Lund University. The authors declare that there is no conflict of interest that would prejudice the impartiality of this scientific work.

\section{References}

Ahrén B 1998 Glucagon-like peptide-1 (GLP-1): a gut hormone of potential interest in the treatment of diabetes. Bioessays 20 642-651.

Ahrén B 2007 Dipeptidyl peptidase-4 inhibitors: clinical data and clinical implications. Diabetes Care 30 1344-1350.

Ahrén B \& Pacini G 2002 Insufficient islet compensation to insulin resistance vs. reduced glucose effectiveness in glucose-intolerant mice. American Journal of Physiology. Endocrinology and Metabolism 283 E738-E744.

Deacon CF \& Holst JJ 2006 Dipeptidyl peptidase IV inhibitors: a promising new therapeutic approach for the management of type 2 diabetes. International Journal of Biochemistry and Cellular Biology 38 831-844.

Dickson LM \& Rhodes CJ 2004 Pancreatic $\beta$-cell growth and survival in the onset of type 2 diabetes: a role for protein kinase B in the Akt? American Journal of Physiology Endocrinology and Metabolism 287 E192-E198.

Doyle ME \& Egan JM 2007 Mechanisms of action of glucagon-like peptide 1 in the pancreas. Pharmacology and Therapeutics 113 546-593. 
Drucker DJ 2003 Glucagon-like peptide-1 and the islet $\beta$-cell: augmentation of cell proliferation and inhibition of apoptosis. Endocrinology 144 5145-5148.

Drucker DJ 2006 The biology of incretin hormones. Cell Metabolism 3 $153-165$.

Drucker DJ \& Nauck MA 2006 The incretin system: glucagon-like peptide-1 receptor agonists and dipeptidyl peptidase-4 inhibitors in type 2 diabetes. Lancet 368 1696-1705.

Egan JM, Bulotta A, Hui H \& Perfetti R 2003 GLP-1 receptor agonists are growth and differentiation factors for pancreatic islet $\beta$ cells. Diabetes Metabolism Research and Reviews 19 115-123.

Gedulin BR, Nikoulina SE, Smith PA, Gedulin G, Nielsen LL, Baron AD, Parkes DG \& Young AA 2005 Exenatide (exendin-4) improves insulin sensitivity and $\beta$-cell mass in insulin-resistant obese $\mathrm{fa} / \mathrm{fa}$ Zucker rats independent of glycemia and body weight. Endocrinology 146 2069-2076.

Greig NH, Holloway HW, De Ore KA, Jani D, Wang Y, Zhou J, Garant MJ \& Egan JM 1999 Once daily injection of exendin-4 to diabetic mice achieves long-term beneficial effects on blood glucose concentrations. Diabetologia 42 45-50.

Gromada J, Holst JJ \& Rorsman P 1998 Cellular regulation of islet hormone secretion by the incretin hormone glucagon-like peptide 1 . Pflugers Archiv 435 583-594.

Henquin JC 2000 Triggering and amplifying pathways of regulation of insulin secretion by glucose. Diabetes 49 1751-1760.

Henquin JC, Ravier MA, Nenquin M, Jonas JC \& Gilon P 2003 Hierarchy of the $\beta$-cell signals controlling insulin secretion. European Journal of Clinical Investigation 33 742-750.

Holz GG 2004a Epac: a new cAMP-binding protein in support of glucagon-like peptide-1 receptor-mediated signal transduction in the pancreatic $\beta$-cell. Diabetes 53 5-13.

Holz GG $2004 b$ New insights concerning the glucose-dependent insulin secretagogue action of glucagon-like peptide-1 in pancreatic B-cells. Hormone and Metabolic Research 36 787-794.

Hui H, Nourparvar A, Zhao X \& Perfetti R 2003 Glucagon-like peptide-1 inhibits apoptosis of insulin-secreting cells via a cyclic $5^{\prime}$-adenosine monophosphate-dependent protein kinase A- and a phosphatidylinositol 3-kinase-dependent pathway. Endocrinology 144 1444-1455.

Jhala US, Canettieri G, Screaton RA, Kulkarni RN, Krajewski S, Reed J, Walker J, Lin X, White M \& Montminy M 2003 cAMP promotes pancreatic $\beta$-cell survival via CREB-mediated induction of IRS2. Genes and Development 17 1575-1580.

Kolterman OG, Buse JB, Fineman MS, Gaines E, Heintz S, Bicsak TA, Taylor K, Kim D, Aisporna M, Wang Y et al. 2003 Synthetic exendin-4 (exenatide) significantly reduces postprandial and fasting plasma glucose in subjects with type 2 diabetes. Journal of Clinical Endocrinology and Metabolism 88 3082-3089.

Li Y, Hansotia T, Yusta B, Ris F, Halban PA \& Drucker DJ 2003 Glucagon-like peptide-1 receptor signaling modulates $\beta$ cell apoptosis. Journal of Biological Chemistry 278 471-478.

Li L, El-Kholy W, Rhodes CJ \& Brubaker PL $2005 a$ Glucagon-like peptide-1 protects $\beta$ cells from cytokine-induced apoptosis and necrosis: role of protein kinase B. Diabetologia 48 1339-1349.

Li Y, Cao X, Li LX, Brubaker PL, Edlund H \& Drucker DJ $2005 b \beta$-cell $\mathrm{Pdx} 1$ expression is essential for the glucoregulatory, proliferative, and cytoprotective actions of glucagon-like peptide-1. Diabetes $\mathbf{5 4}$ 482-491.

Montrose-Rafizadeh C, Yang H, Rodgers BD, Beday A, Pritchette LA \& EngJ 1997 High potency antagonists of the pancreatic glucagon-like peptide-1 receptor. Journal of Biological Chemistry 272 21201-21206.

Pacini G, Thomaseth K \& Ahrén B 2001 Contribution to glucose tolerance of insulin-independent vs. insulin-dependent mechanisms in mice. American Journal of Physiology Endocrinology and Metabolism 281 E693-E703.

Park S, Dong X, Fisher TL, Dunn S, Omer AK, Weir G \& White MF 2006 Exendin-4 uses Irs2 signaling to mediate pancreatic $\beta$ cell growth and function. Journal of Biological Chemistry 281 1159-1168.
Parkes D, Jodka C, Smith P, Nayak S, Rinehart L, Gingerich R, Chen K \& Young RA 2001 Pharmacokinetic action of exendin-4 in the rat: comparison with glucagon-like peptide-1. Drug Development Research 53 260-267.

Perfetti R, Zhou J, Doyle ME \& Egan JM 2000 Glucagon-like peptide-1 induces cell proliferation and pancreatic-duodenum homeobox-1 expression and increases endocrine cell mass in the pancreas of old, glucose-intolerant rats. Endocrinology 141 4600-4605.

Simonsson E \& Ahrén B 1998 Potentiated $\beta$-cell response to nonglucose stimuli in insulin-resistant C57BL/6J mice. European Journal of Pharmacology 350 243-250.

Skalhegg BS \& Tasken K 2000 Specificity in the cAMP/PKA signaling pathway. Differential expression,regulation, and subcellular localization of subunits of PKA. Frontiers in Bioscience 5 D678-D693.

Skoglund G, Lundquist I \& Ahrén B 1988 Selective $\alpha$ 2-adrenoceptor activation by clonidine: effects on $45 \mathrm{Ca} 2+$ efflux and insulin secretion from isolated rat islets. Acta Physiologica Scandinavia 132 289-296.

Sörhede Winzell M \& Ahrén B 2004 Glucagon-like peptide-1 and islet lipolysis. Hormone and Metabolic Research 36 795-803.

Stoffers DA, Kieffer TJ, Hussain MA, Drucker DJ, Bonner-Weir S, Habener JF \& Egan JM 2000 Insulinotropic glucagon-like peptide 1 agonists stimulate expression of homeodomain protein IDX-1 and increase islet size in mouse pancreas. Diabetes 49 741-748.

Taylor SS, Kim C, Vigil D, Haste NM, Yang J, Wu J \& Anand GS 2005 Dynamics of signaling by PKA. Biochimica et Biophysica Acta $\mathbf{1 7 5 4}$ 25-37.

Tuttle RL, Gill NS, Pugh W, Lee JP, Koeberlein B, Furth EE, Polonsky KS, Naji A \& Birnbaum MJ 2001 Regulation of pancreatic $\beta$-cell growth and survival by the serine/threonine protein kinase Akt1/PKB $\alpha$. Nature Medicine 7 1133-1137.

Wang Q \& Brubaker PL 2002 Glucagon-like peptide-1 treatment delays the onset of diabetes in 8 week-old db/db mice. Diabetologia 45 1263-1273.

Wang X, Zhou J, Doyle ME \& Egan JM 2001 Glucagon-like peptide-1 causes pancreatic duodenal homeobox-1 protein translocation from the cytoplasm to the nucleus of pancreatic $\beta$-cells by a cyclic adenosine monophosphate/protein kinase A-dependent mechanism. Endocrinology 142 1820-1827.

Winzell MS \& Ahrén B 2004 The high-fat diet-fed mouse: a model for studying mechanisms and treatment of impaired glucose tolerance and type 2 diabetes. Diabetes 53 S215-S219.

Wrede CE, Dickson LM, Lingohr MK, Briaud I \& Rhodes CJ 2002 Protein kinase B/Akt prevents fatty acid-induced apoptosis in pancreatic $\beta$-cells (INS-1). Journal of Biological Chemistry 277 49676-49684.

Xu G, Stoffers DA, Habener JF \& Bonner-Weir S 1999 Exendin-4 stimulates both $\beta$-cell replication and neogenesis, resulting in increased $\beta$-cell mass and improved glucose tolerance in diabetic rats. Diabetes 48 2270-2276.

Young AA, Gedulin BR, Bhavsar S, Bodkin N, Jodka C, Hansen B \& Denaro M 1999 Glucose-lowering and insulin-sensitizing actions of exendin-4: studies in obese diabetic (ob/ob, $\mathrm{db} / \mathrm{db})$ mice, diabetic fatty Zucker rats, and diabetic rhesus monkeys (Macaca mulatta). Diabetes 48 1026-1034.

Del Zotto H, Borelli MI, Flores L, Garcia ME, Gomez Dumm CL, Chicco A, Lombardo YB \& Gagliardino JJ 2004 Islet neogenesis: an apparent key component of long-term pancreas adaptation to increased insulin demand. Journal of Endocrinology 183 321-330.

Received in final form 15 November 2007

Accepted 6 December 2007

Made available online as an Accepted Preprint

7 December 2007 